\title{
Nutrient evaluation of Couroupita guianensis fruits and flowers and effect of feeding Couroupita guianensis flowers on growth and haemato - biochemical parameters in Wistar rats
}

\author{
Nisna Niyas ${ }^{1}$, K. Jasmine Rani ${ }^{2}$ and K. Ally ${ }^{3}$ \\ Department of Animal Nutrition, College of Veterinary and Animal Sciences, \\ Mannuthy - 680651, Thrissur, Kerala. Kerala Veterinary and Animal Sciences University.
}

Citation: Niyas, N., Rani, K. J., Ally, K. 2021. Nutrient evaluation of Couroupita guianensis fruits and flowers and effect of feeding Couroupita guianensis flowers on growth and haemato - biochemical parameters in Wistar rats. J. Vet. Anim. Sci. 52(1): 32-35.

DOI: https://doi.org/10.51966/jvas.2021.52.1.32-35

Received : 26.10.2020

Accepted: 28.11.2020

Published: 01.01.2021

\begin{abstract}
A study was undertaken to access the nutritive value of fruits and flowers of cannon ball tree (Couroupita guianensis Aubl.) harvested from different trees at the College of Veterinary and Animal Sciences, Mannuthy, Thrissur. The samples were oven dried at $100^{\circ} \mathrm{C}$ until constant weight was obtained for dry matter determination. The dried samples were ground and subjected to proximate analysis. Results showed that Couroupita guianensis fruit and flowers contain moderate crude protein, nitrogen free extract and total ash. For animal experimentation fifteen healthy Wistar rats of three weeks of age were selected and divided into three groups of five each and allotted randomly to three experimental treatments $T_{1}$ (control), $T_{2}(T 1+1 \%$ Couroupita guianensis flower (CGF) on dry matter basis), $T_{3}(T 1+2 \%$ CGF on dry matter basis). All the experimental animals were fed with feed containing $24 \% \mathrm{CP}$ and $3000 \mathrm{kcal} / \mathrm{kg}$ energy and were fed as per NRC standard. Feeding trial was conducted for a period of 30 days. The results showed that dry matter intake and body weight of animals were similar among the groups. Haemato-biochemical parameters such as haemoglobin, total protein and plasma glucose were similar among the groups whereas the triglycerides and total cholesterol were significantly lower in CGF supplemented group.
\end{abstract}

Key words: Couroupita guianensis flower, Wistar rats, Growth, Blood

Couroupita guianensis Aubl. (Cannon ball) is a large deciduous tropical tree 20-30 metres in height commonly called "Kailashpati". The leaves, up to $15 \mathrm{~cm}$ long, are simple with serrate margin; the flowers are yellow, reddish and pink with a stunning fragrance. The flowers which grow on the trunk are aromatic, large and waxy and look like a Shivalinga and it's pollen is snake shaped. Fruits are large and globose with a woody look like big rusty cannonballs hanging in clusters or like balls on a string. The fruit contains small seeds in a white, unpleasant smelling edible jelly (Kumar et al., 2017). The plant is indigenous to rainforest of the Guianas in North-eastern South America.

\footnotetext{
1. BVSc Scholar, CVAS, Mannuthy.

2. Assistant Professor. 9387091476, jasminerani@kvasu.ac.in

3. Professor and Head
}

Copyright: (C) 2021 Nisna et al. This is an open access article distributed under the terms of the Creative Commons Attribution 4.0 International License (http://creativecommons.org/licenses/by/4.0/), which permits unrestricted use, distribution, and reproduction in any medium, provided the original author and source are credited. 
It is a popular ornamental in Caribbean and South East Asian botanical gardens and listed as a rare tree and flower in India.

The components of this tree have many medicinal properties such as antioxidant (Pinheiro et al., 2010), anthelmintic (Regina and Uma Rajan, 2012), anti-inflammatory (Gupta et al., 2012), antiulcer (Elumalai et al., 2012) and antibacterial (Sivakumar et al., 2015). Researches to evaluate the nutritive value of Couroupita guianensis fruit and flower and feeding trials as feed additive are very scanty. Hence this research work was done to evaluate the nutritive value of the Couroupita guianensis fruit and flower and to study the effect of supplementation of CGF on growth performance in Wistar rats.

\section{Materials and Methods}

Fruits and flowers of cannon ball tree were harvested from different trees from the College of Veterinary and Animal Sciences, Mannuthy (geographical coordinates $10.5332^{\circ}$ $\left.\mathrm{N}, 76.2641^{\circ} \mathrm{E}\right)$. The samples collected were sliced and oven dried at $100{ }^{\circ} \mathrm{C}$ until constant weight was obtained for dry matter determination. The dried samples were grinded and subjected to proximate analysis as per AOAC 2016. The samples then analysed for nutrient content viz. Crude Protein (CP), Crude Fiber (CF), Ether Extract (EE), Total Ash (TA), Acid insoluble ash (AIA) and Nitrogen free extract (NFE).

The experimental animals of this study were fifteen male Wistar rats with good health selected from Small animal breeding station (SABS), Mannuthy. The rats were allotted randomly to three experimental treatments $T_{1}$ (control), $\mathrm{T}_{2}$ (T1 + 1\% Couroupita guianensis flower (CGF) on dry matter basis) and $\mathrm{T}_{3}$ ( $\mathrm{T} 1$ $+2 \%$ CGF on dry matter basis) uniformly. All the experimental animals were fed with feed containing $24 \% \mathrm{CP}$ and $3000 \mathrm{kcal} / \mathrm{kg}$ energy.

The experimental animals were kept individually in clean and dry cage with good air circulation with amenities for feeding and watering. The feed was given in the morning after weighing the quantity. Potable water was given ad libitum to all the animals. Ambient conditions were maintained in the experimental house. Daily recording of the dry matter intake was performed. Also, the body weights of the rats were taken weekly and based on this data, the feed offered was revised.

Blood samples were collected from all the animals at the end of the experiment to estimate haemoglobin (cyanmetahemoglobin method), total protein (Biuret method), glucose (GOP-PAP methodology), total cholesterol and triglycerides (enzymatic colorimetric methods) using standard kits supplied by Agappe diagnostics Ltd, Ernakulam, India. Feed samples were analysed for proximate principles (AOAC, 2016). Analysis of Variance (Snedecor and Cochran, 1994) method was used for the statistical analysis.

\section{Results and Discussion}

Chemical composition of Couroupita guianensis fruit and flower (DM basis) is presented in Table 1. Couroupita guianensis fruit and flower contain moderate CP, NFE and TA. Shah et al., 2012 observed comparable TA value in the fruit of Couroupita guianensis.

Initial body weight of rats in treatments $\mathrm{T}_{1} \mathrm{~T}_{2}$ and $\mathrm{T}_{3}$ were 149.60, 148.0 and $150.6 \mathrm{~g}$ respectively. Body weight of rats recorded at weekly intervals and final body weight was 208.6, 214.2 and $209.0 \mathrm{~g}$, respectively for $\mathrm{T}_{1} \mathrm{~T}_{2}$ and $T_{3}$ at the end of experiment. There was no significant difference $(P>0.05)$ in body weight between the dietary treatments. Total weight gain and average dry matter intake of animals were similar in all the dietary treatments and presented in Table 3. James et al. (2002) and Manjula et al. (2016) observed similar total dry matter intake in rats.

Data on haemato-biochemical studies have been given in Table 4. The haemoglobin concentrations at the end of the experiment for group $T_{1}, T_{2}$ and T3 were13.72, 13.78 and $14.02 \mathrm{~g} / \mathrm{dL}$ respectively and were similar in all the groups indicating that dietary incorporation of CGF powder did not affect these parameters to any significant effect. The average plasma protein concentrations at the end of the experiment for group $\mathrm{T}_{1}, \mathrm{~T}_{2}$ and T3 were 6.31, 6.20 and $6.24 \mathrm{~g} / \mathrm{dL}$, respectively. The average 
Table 1. Chemical composition of experimental feed \% (DM basis)

\begin{tabular}{|l|l|l|l|}
\hline \multicolumn{1}{|c|}{ Parameters } & $\mathbf{T}_{\mathbf{1}}$ & $\mathbf{T}_{\mathbf{2}}$ & $\mathbf{T}_{\mathbf{3}}$ \\
\hline Dry matter (DM) & 91.66 & 91.05 & 91.25 \\
\hline Crude Protein (CP) & 24.04 & 24.56 & 24.61 \\
\hline Ether extract (EE) & 5.12 & 5.64 & 5.81 \\
\hline Crude fibre (CF) & 4.99 & 5.08 & 5.14 \\
\hline Total Ash (TA) & 6.12 & 6.44 & 6.72 \\
\hline Nitrogen free extract (NFE) & 59.73 & 58.28 & 57.72 \\
\hline Acid insoluble ash (AIA) & 0.84 & 0.79 & 0.82 \\
\hline
\end{tabular}

Table 2. Chemical composition of Couroupita guianensis fruit and flower \% (DM basis)

\begin{tabular}{|l|l|l|}
\hline Parameters & Fruit & Flower \\
\hline Dry matter (DM) & 14.13 & 7.82 \\
\hline Crude protein (CP) & 7.60 & 11.23 \\
\hline Ether extract (EE) & 9.13 & 4.06 \\
\hline Crude fibre (CF) & 13.58 & 6.78 \\
\hline Total Ash (TA) & 11.43 & 8.94 \\
\hline Nitrogen free extract (NFE) & 58.26 & 68.99 \\
\hline
\end{tabular}

Table 3: Body weight $(\mathrm{g})$ and dry matter intake $(\mathrm{g})$ of experimental rats

\begin{tabular}{|l|l|l|l|}
\hline \multicolumn{1}{|c|}{ Parameters } & \multicolumn{1}{c|}{$\mathbf{T}_{\mathbf{1}}$} & \multicolumn{1}{c|}{$\mathbf{T}_{\mathbf{2}}$} & \multicolumn{1}{c|}{$\mathbf{T}_{\mathbf{3}}$} \\
\hline Initial body weight $(\mathrm{g})$ & $149.60 \pm 3.23$ & $148.00 \pm 2.92$ & $150.60 \pm 3.08$ \\
\hline Final body weight $(\mathrm{g})$ & $208.60 \pm 5.90$ & $214.2 \pm 5.24$ & $209.00 \pm 6.50$ \\
\hline Total weight gain $(\mathrm{g})$ & $59.00 \pm 8.75$ & $66.20 \pm 3.92$ & $58.40 \pm 6.14$ \\
\hline Total dry matter intake (g/animal) & $332.60 \pm 9.21$ & $337.60 \pm 11.66$ & $322.20 \pm 9.64$ \\
\hline
\end{tabular}

Table 4. Haemato- biochemical parameters of experimental rats

\begin{tabular}{|l|l|l|l|}
\hline Parameters & \multicolumn{1}{|c|}{ T1 } & \multicolumn{1}{c|}{ T2 } & \multicolumn{1}{c|}{ T3 } \\
\hline Haemoglobin $(\mathrm{g} / \mathrm{dL})$ & $13.72 \pm 2.62$ & $13.78 \pm 2.28$ & $14.02 \pm 1.53$ \\
\hline Total Protein $(\mathrm{g} / \mathrm{dL})$ & $6.31 \pm 0.05$ & $6.20 \pm 0.07$ & $6.24 \pm 0.05$ \\
\hline Glucose $(\mathrm{mg} / \mathrm{dL})$ & $88.73 \pm 0.36$ & $88.77 \pm 0.34$ & $89.38 \pm 0.25$ \\
\hline Total Cholesterol $(\mathrm{mg} / \mathrm{dL})$ & $78.42 \pm 0.33^{\mathrm{a}}$ & $77.01 \pm 0.31^{\mathrm{b}}$ & $76.23 \pm 0.26^{\mathrm{b}}$ \\
\hline Triglycerides $(\mathrm{mg} / \mathrm{dL})$ & $44.56 \pm 0.28^{\mathrm{a}}$ & $41.77 \pm 0.36^{\mathrm{b}}$ & $40.40 \pm 0.31^{\mathrm{b}}$ \\
\hline
\end{tabular}

plasma glucose values were $88.73,88.77$ and $89.38 \mathrm{mg} / \mathrm{dL}$ for group $\mathrm{T}_{1}, \mathrm{~T}_{2}$ and $\mathrm{T} 3$ respectively. The average serum cholesterol and triglyceride values were 78.42, 44.56, 77.01, 41.77 and $76.23,40.40 \mathrm{mg} / \mathrm{dL}$, respectively for group $\mathrm{T}_{1}$, $\mathrm{T}_{2}$ and $\mathrm{T}_{3}$.

The results revealed that the serum biochemical values are within the normal range reported to the species. There was no significant difference in the values of serum total protein and glucose. In contrary to this Morankar et al. (2013) reported that supplementation of the aqueous and methanolic extracts of Couroupita guianensis flower $(100 \mathrm{mg} / \mathrm{kg})$ significantly $(p<0.05)$ reduced the blood glucose level in alloxan induced diabetic mice and has antidiabetic activity.

The values of total cholesterol and triglycerides were significantly lower $(p<0.05)$ in CGF supplemented group compared to the control group. The hypercholesteraemic effects may be due to the polyphenolics and flavonoids present in the CGF which positively modify lipid profile. In agreement with present results Ramyasai et al. (2013) also reported that treatment with methanolic extract of Couroupita guianensis Aubl. flowers significantly decreased the total serum cholesterol, triglycerides, 
low density lipoproteins, very low-density lipoproteins and increased the high-density lipoproteins in obese rats and was comparable with that of standard Atorvastatin. Hassan et al. (2018) also reported that supplementation of extracts of Couroupita guianensis leaves to rats at a dose rate of $1.25 \mathrm{~g} / \mathrm{kg}$ showed significant reduction in the serum cholesterol level.

\section{Conclusion}

It can be concluded that Couroupita guianensis flower has anti-hyperlipidemic and atherosclerotic properties and that it can be used as a feed additive with anti-atherogenic property without any adverse effect on their growth in Wistar rats. Furtherresearch is needed to find the phytochemical profile and to detect the active principles for the beneficial health effects.

\section{References}

AOAC [Association of Official Analytical Chemists]. 2016. Official Methods of Analysis. (20 ${ }^{\text {th }}$ Ed.). Association of Official Analytical Chemists, Washington DC, 1885p.

Elumalai, A., Naresh, V., Eswaraiah, M.C., Narendar, P. and Kumar, R. 2012. Evaluation of Antiulcer Activity of Couroupita guianensis Aubl. leaves. Asian J. Pharmaceut.Sci. 2: 64-66.

Gupta, V. H., Gunjal, M. A., Wankhede, S. S. and Deshmukh, V.S.2012. Neuropharmacological Evaluation of the Methanolic Extract of Couroupita guianensis Aubl. Flower in Mice. Int. J. Pharmaceut. Pharmacol. Res. 1: 242246. Hassan, M. M., Islam, M. M., Uddin, S., Bhowmik, A. and Rokeya, B., 2018. Antihyperglycemic potential of ethanolic extract of Couroupita guianensis on Streptozocin induced experimental diabetic rat model. Asian J. Res. Med. Pharm. Sci. 5(3): 1-10.

James, K. A. C., Butts, C. A., Koolaard, J. P., Donaldson, H. E., Scott, M. F. and Moughan, P. J. The effect of food dry matter intake on the flow of amino acids at the terminal ileum for rats fed an enzyme-hydrolysed casein-based diet. J. Sci. Food. Agric. 82: 1128-1135.
Kumar, V., Tiwari, A. and Ashwin, S. 2017. Couroupita guianensis : A potential medicinal tree. Van Sangyan. 4: 30-34.

Manjula, K. and Krishna, R. 2016. Feed efficiency and sero bichemical profile of Wistar rat fed with spirulina as functional food. Curr. Res. Nutr. Food. Sci. 4: 2754.

Morankar, P.G., Dhake, A.S., Kumbhare, M.R., Ushir, Y.V., Surana, A. R. and Patil, S.D. 2013. An evaluation of the antidiabetic effects of Couroupita guianesis aubl. flowers in experimental animals. Indo Am. J. Pharm. Res. 3: 3114-3122.

Pinheiro, M. M. G., Bessa, S. O., Fingolo, C. E., Kuster, R. M., Matheus, M. E., Menezes, F. S. and Fernandes, P.S. 2010. Antinociceptive activity of fractions from Couroupita guianensis Aubl. leaves. J. Ethnopharmacol. 127: 407-413.

Ramyasai, K., Manohar babu S., Vadivel, K. 2013.Anti-obesity and atheroscelerotic activity of methanolic extract of Couroupita guianensis Aubl. flowers in rats fed with high fat diets, Int. J. Universal Pharm. Bio Sci. 2(6): 288-300.

Regina, V. and Uma Rajan, K.M. 2012. Phytochemical analysis, antioxidant and antimicrobial studies of fruit rind of Couroupita guianensis (AUBL). Int. J. Curr. Sci. 262-267.

Shah, G. N., Shete, S. A., Patil, V. S., Patil, K. D., Killedar, S. G. 2012. Standardization and anti-bacterial activity of Couroupita guianensis fruit pulp extract. Int. J. Pharmacogn. Phytochem. Res. 4: 185189.

Sivakumar, T., Rathimeena, T., Shankar, and Ponmanickam, P. 2015. Production of silver nanoparticles synthesis of Couroupita guianensis plant extract againsthuman pathogen and evaluations of antioxidant properties. Int. J. Life Sci. 3: 333-340.

Snedecor, G.W. and Cochran, W.G. 1994. Statistical Methods. (8 $8^{\text {th }} \mathrm{Ed}$.). The lowa State University press, Ames, 503p. 